REVISTA de

PEDAGOGIE

http://revped.ise.ro

Print ISSN 0034-8678; Online ISSN: 2559 - 639X

\title{
THE IMPACT OF EMERGENCY REMOTE TEACHING ON SCIENCE PRE-SERVICE TEACHERS AT THE WEST UNIVERSITY OF TIMIȘOARA
}

Impactul predării la distanță asupra viitorilor profesori de științe ale naturii în cadrul formării inițiale la Universitatea de Vest din Timișoara

\section{Dana CRĂCIUN}

\author{
Journal of Pedagogy, 2020 (2), 7 - 30 \\ https://doi.org/10.26755/RevPed/2020.2/7
}

The online version of this article can be found at: http://revped.ise.ro/en/2020/

\section{(c) (1) (5) (2)}

This work is licensed under the Creative Commons Attribution-NonCommercial-ShareAlike 4.0 International License. 94042, USA.

Published by:

Centrul Național de Politici Și Evaluare în Educație

UNITATEA DE CERCETARE ÎN EDUCAȚIE

http://www.ise.ro/

https://rocnee.eu/

Further information about Revista de Pedagogie - Journal of Pedagogy can be found at:

Editorial Policy: http://revped.ise.ro/editorial-policy/

Author Guidelines: http://revped.ise.ro/en/author-guidelines/ 


\title{
THE IMPACT OF EMERGENCY REMOTE TEACHING ON SCIENCE PRE-SERVICE TEACHERS AT THE WEST UNIVERSITY OF TIMIŞOARA
}

\section{Dana Crăciun*}

\author{
West University of Timişoara, \\ Teacher Training Department, \\ Timişoara, Romania \\ craciun.dana@e-uvt.ro
}

\section{Abstract}

According to the UNESCO reports, the health crisis caused by SARS-COV-2 affected more than 1.7 billion students from around 150 countries worldwide this past spring. Teachers at all levels of education were forced to switch to digital resources and tools and were required to transition and adapt promptly to remote teaching. This transition took place also within the Teacher Training Department at the West University of Timisoara. Teachers together with their students had to find pragmatic, technology-based, creative solutions that would allow them to carry out the remote teaching, learning and assessment activities at a level that would ensure the development of the desired skills and the achievement of the desired learning outcomes.

This paper explores the way in which the teaching, learning, and assessment activities have been adapted for emergency remote teaching at the West University of Timisoara. We focus on the first and second levels of the Teacher Training Program offered to future science teachers at this university.

We present the adopted strategies, communication tools, and the applications used to deliver the proposed teaching, learning, and assessment activities. Furthermore, we identify the most common technological and pedagogical difficulties encountered throughout these activities, as well as the future science teachers' concerns regarding the transition to remote teaching.

* Senior Lecturer, West University of Timişoara, Teacher Training Department, Timişoara, Romania. 
We conclude that the health crisis has had both negative and positive influences on the training process of future science teachers at the West University of Timisoara, providing a unique opportunity that allowed both teachers and their students to jointly discover effective remote teaching-learning-assessment approaches.

Keywords: challenges and opportunities, emergency remote teaching, preservice science teachers.

\section{Rezumat}

Criza sanitară generată de SARS-COV 2 a afectat, în primăvara acestui an, la nivel mondial, peste 1,7 miliarde de elevi din peste 150 ări, conform rapoartelor UNESCO.

Profesorii, la toate nivelurile de învă ământ, au fost nevoi i să utilizeze instrumente şi resurse digitale şi să se adapteze rapid pentru a continua predarea online, fapt petrecut şi în cadrul DPPD (Departamentul pentru Pregătirea Personalului Didactic) din UVT (Universitatea de Vest din Timişoara). Studen ii împreună cu formatorii lor au fost nevoi i să găsescă solu ii pragmatice bazate pe tehnologie, creative de multe ori, care să le permită desfăşurarea activită ilor didactice online, la un nivel care să conducă la formarea competen elor şi la ob inerea rezultatelor dorite ale învă ării.

Articolul de fa ă explorează modul în care au fost adaptate pentru predarea la distan ă activită ile de predare-învă are-evaluare la nivelul UVT, dar şi, specific, în cadrul programului de formare psihopedagogică nivel 1 şi 2, ofertat viitorilor profesori de stiin e din UVT.

Sunt prezentate strategiile abordate, modalită ile de comunicare sincrone şi asincrone, aplica iile utilizate în activită ile propuse studen ilor, modalită ile de evaluare şi feedback utilizate. De asemenea, sunt identificate probleme de natură tehnică sau de învă are şi îngrijorările studen ilor cu privire la trecerea la învă area la distan ă.

Concluzia noastră este că situa ia de criză a avut atât influen e negative, cât şi pozitive asupra procesului de pregătire a viitorilor profesori de ştiin e din UVT, fiind o provocare prin care am descoperit împreună modalită $i$, considerăm eficiente, de predare-învă are-evaluare în mediul online.

Cuvinte-cheie: predarea la distan ă, studen i de la ştiin e, provocări şi oportunită $i$. 


\section{Introduction}

On March 11, 2020, the SARS-COV-2 crisis led to the adjournment of faceto-face courses at all higher education institutions in Romania, including at the West University of Timisoara (WUT) http://www.uvt.ro/. From that moment, the challenge at university level was to continue the teaching process entirely in an online environment while maintaining optimal conditions and the highest possible level of quality of the teaching process. In this regard, WUT has been in an favourable position as it was already in a process of digitization, with IT services providing teachers and students of the WUT access to various online eLearning platforms, Google Classroom, Microsoft Office 365 or Moodle https://elearning.e-uvt.ro/ and EduRoam network (https://www.eduroam.org/). Thus, the challenge for our teachers was in fact related to the adequate use of these tools for teaching entirely online, with the focus being on the pedagogical aspects.

A crisis committee was created at the level of WUT in order to manage all the problems caused by the health crisis and to establish a set of general measures for the continuation of the teaching process (Bran \& Grosseck, 2020). These measures were later customized within each faculty, including the Department of Teacher Training (DPPD).

The general set of measures at the WUT level included the organization of webinars for teachers with various technical solutions accessible at institutional level that could be used in online teaching, and the creation of dedicated webpages where information and tutorials were posted (https:// it.uvt.ro/) regarding the tools recommended to be used online in the teaching activity (https://resurse.e-uvt.ro/).

Since March 11, 2020, the WUT Board of Directors regulated the online teaching activities, until the end of the academic year. After consulting the teachers at the WUT, the Board of Directors opted to end the academic year according to the structure already in force for the academic year 20192020 and decided that both the summer and autumn exam sessions, as well as the final exams for all WUT faculties, were to be held online https:// www.uvt.ro/ro/uvt/organizare/consiliul-de-administratie/sedinte-hotarari/. 
This is the context in which the Teacher Training Department (DPPD) at WUT has been operating since March 11, 2020.

Moving the teaching and assessment process to the online environment led to a major change in the way DPPD teachers conducted their teaching and interacted with students and colleagues at WUT.

This article highlights the way in which this change was implemented, starting with the didactic strategy adopted, the tools and resources used, the communication and interaction with students, but also with the management of department-specific activities, such as the Teaching Practice. We identified both the opportunities and the risks of the adopted approach, taking into account the opinions of both the DPPD teachers as well as the students who will be the future science teachers (specializations Mathematics, Computer Science, or Physics) and participated in the activities within the Didactics and Teaching Practice courses.

This article also presents the way in which the health crisis and implicitly the Emergency-Remote Teaching (ERT) approach have left their mark on the training of future science teachers. We identify diverging perspectives on the online teaching process from students and teachers from DPPD, as well as similar opinions on communication and interaction in an entirely online environment.

\section{DPPD's strategy for ERT}

In order to implement at DPPD level the measures established by the WUT, the teaching staff in charge of CAI (Computer Assisted Instruction) and/ or the Didactics of Informatics created a support group for the teachers in the department. This support group established several measures to reorganize the activity and sustain the online teaching process which were folded on the recommendations of international bodies such as UNESCO, World Bank, International Association of Universities (IAU), The Commonwealth of Learning (COL), Educause, etc.

First of all, this support group took into account that ERT did not actually 
involve an online transition according to all the classic rules of this type of education, trying through the measures taken to be able to continue the teaching process quickly and without changing the curriculum or methodology (Hodges et al., 2020).

Secondly, this support group sought to take advantage of the experience of educational institutions that have already faced this transition to online teaching (Bao, 2020; McAleavy \& Gorgen, 2020).

Thirdly, this group tried to make small changes in the teaching activity that would enhance the quality teaching in the digital age, even after the pandemic crisis (Bates, 2020; Doucet et al., 2020).

As steps that effectively target the teaching process, we highlight:

1. Keeping in touch with all students, using all existing means of communication before the health crisis (email, WhatsApp, Facebook, Google Classroom, etc.);

2. Quickly choosing a video conferencing platform and continuing the synchronous activities. The platform Google Meet was chosen which was part of the platforms provided by WUT and which in this case had the advantage of being folded on the eLearning platform already used at DPPD, i.e. Google Classroom. In a study conducted by the Center for Academic Development (CDA) at the WUT level, by the end of April 2020 , data show that $87 \%$ of the DPPD teachers used Google Classroom and $100 \%$ Google Meet (Bunoiu et al., 2020); and

3. Reorganizing teaching resources and rethinking the teaching strategy so as to propose to students both synchronous and asynchronous activities according to the principles of flexible learning (Huang et al., 2020), dividing the teaching content into smaller units to help students focus (Bao, 2020; Bates, 2019), etc.

The underlying desire was to restructure the courses and seminar activities so that they would be folded on individual topics, students being informed through eLearning platforms about the learning outcomes, contents and assessments expected, and being frequently asked to browse various learning resources in advance (flipped classroom strategy).

Thus, each teacher from DPPD rethought their own teaching-evaluation 
process with respect to

- the selection of appropriate online tools;

- the management of their teaching activity and resources - according to the principles of flexible learning;

- the organization of the teaching practice activity for students (where applicable);

- the communication with students;

- the evaluation of students' activity, with emphasis on formative evaluation and feedback (generally chosen alternative methods of summative evaluation).

The strategy adopted at DPPD level is summarized in Figure 1 (https:// coggle.it/diagram/). 


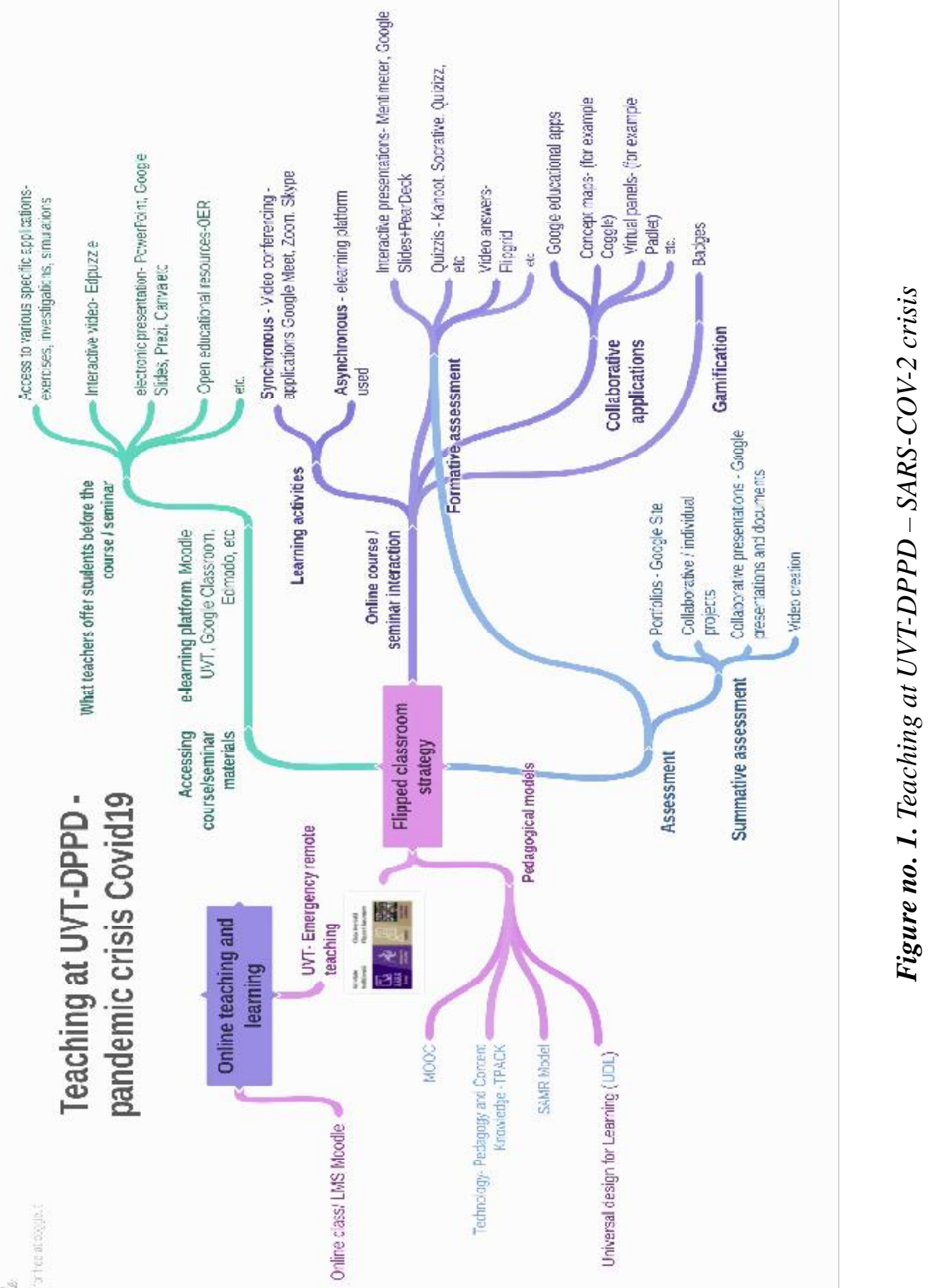


Teachers in the DPPD support group presented to their colleagues the potentially useful resources and tools, a comprehensive description of free web-based digital tools being taken from Bower and Torrington's (2020) paper. They also proposed to use the tools recommended by UNESCO, useful for distance teaching in pre-university education, considering that DPPD students will be future science teachers.

Table 1 presents a detailed view on different ways of organizing the training proposed to DPPD students, wherein useful tools for teachers and students have been exemplified. It should be noted that this strategy can be used in future online teaching activities by DPPD graduates who will teach in preuniversity education. 


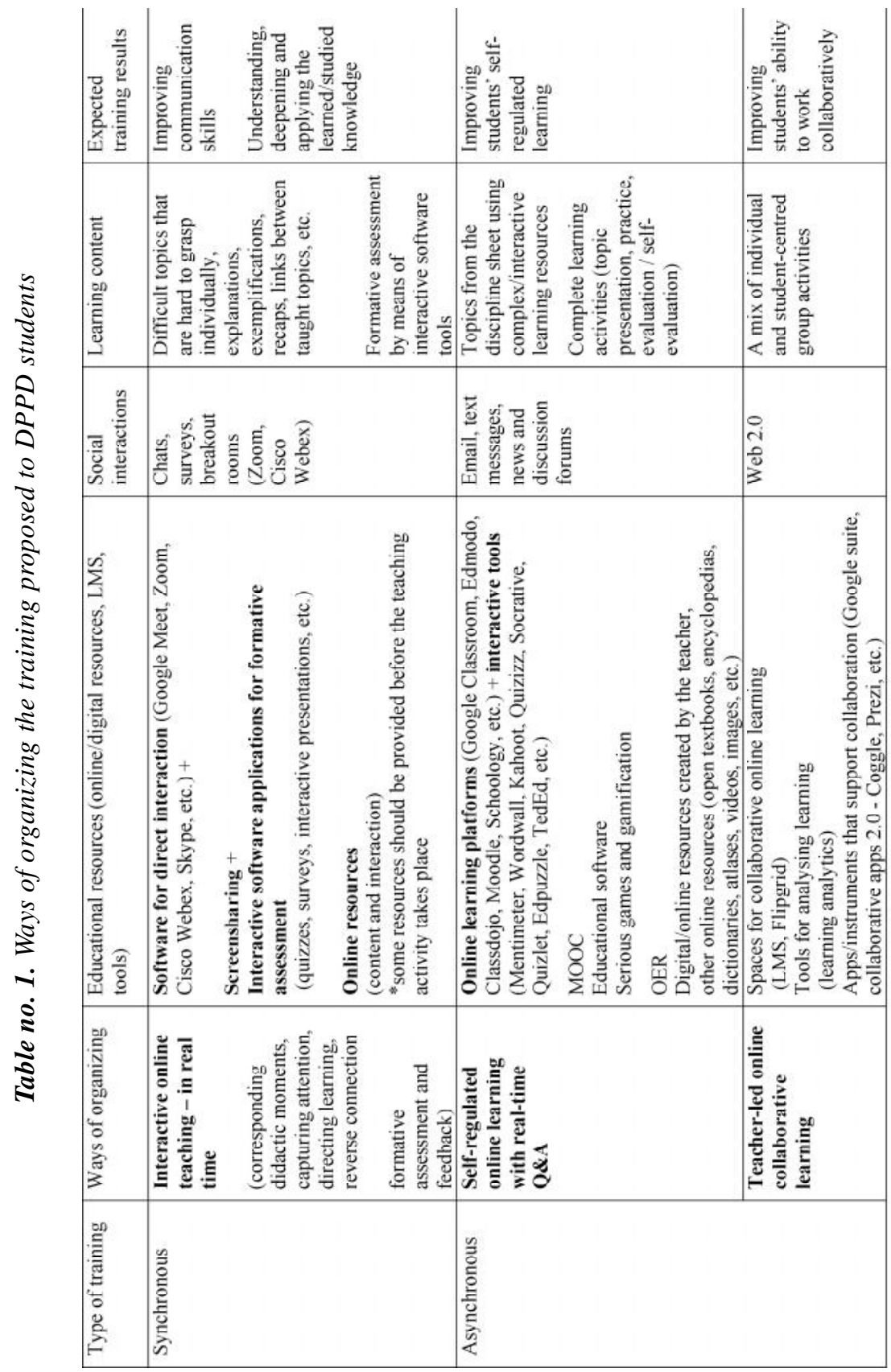


All measures implemented to reorganize teaching in DPPD considered the interests of students, aiming at

- ensuring access to online education;

- training learning skills using self-learning;

- the successful completion of the academic year, including the graduation exam for the graduate years;

- ensuring communication with teachers and maintaining the unity of student groups.

All these measures outlined the framework in which teachers at DPPD started and carried out the online teaching activity in the disciplines Pedagogical Practice, Didactics of Specialization, and CAI from Level 1 and 2 of the Teacher Training Program with preservice science teachers.

\section{Methodology}

This study targets preservice science teachers at Level 1 and Level 2, from our teacher training program.

We started from the assumption that the SARS-COV-2 health crisis and the transfer to the online environment of teaching activities influenced the entire psycho-pedagogical training program of future science teachers in DPPD, both regarding teaching activities and the evaluation process.

Our objective was to identify the extent to which training in ERT was affected, from the perspective of preservice science teachers. Their opinions were compared with those of the teachers from DPPD. As ERT also assumed a certain heterogeneity in the approach to the teaching process, we chose to analyze the opinions of a homogeneous group of preservice science teachers, also finding support in the learning activities proposed in a common discipline, i.e. the Teaching Practice course in the second semester of the academic year 2019-2020.

It is noteworthy that this discipline has a specificity with respect to the other disciplines because it involves teaching in various schools. 
After online teaching practice activities, we applied at the beginning of May 2020 a short questionnaire, the results of which we compared with the answers of teachers from DPPD to a questionnaire on online teaching (with similar questions) applied at WUT around the same time.

The questionnaire for students was structured in 3 parts: the first part focused on the use of ICT in current activities and the general attitude towards online learning and teaching activities, technical and learning problems identified by preservice teachers; the second part addressed concerns about the transition to ERT, but also the way in which the finalities of the psychopedagogical training program were achieved; and the third part aimed at the concerns and opportunities regarding the transition to emergency distance learning, identified following the effective teaching practice activities.

The questionnaire was developed with the QuestionPro, a tool offered by the university and accessible free of charge to WUT teachers. The preservice science teachers filled-in the questionnaire online.

We briefly present some of the teaching activities proposed to the group targeted by this study, within the Pedagogical Practice, activities that we consider to have influenced the favourable responses of preservice teachers, while also being an example of good practices for their future teaching activity in the online environment (if the case).

\subsection{Organizing teaching activities for preservice science teachers during ERT}

The Teaching Practice being coordinated at department level in a unitary way, the DPPD council decided to form distinct groups on Google Classroom for each specialization and level and invite all the tutor teachers from the schools, as co-teachers of the respective discipline.

The activity as a whole was minimally modified: the teaching activities (the effective teaching activities and assistance classes to tutors and colleagues) and the evaluation mode (practice portfolio) were kept unaltered, and the effective organization of the activity according to ERT for each pre-university school involved was left to the discretion of the teacher in the DPPD. 
Thus, DPPD students had different teaching experiences, even within a single specialization, involving various strategies and tools, the teaching being done on WhatsApp, e-mail, Google Classroom, Moodle or on the school's platform.

In this context, in the case of the exemplified discipline, the following strategy was chosen:

1. Building a WhatsApp group for tutors in order to easily keep in touch regardless of the tools used by each of them.

2. Creating Google classes for each specialization at Level 1, respectively one for all the 3 specializations in the case of Level 2 (the emphasis being placed here, both on the didactics of science and on the teaching practice, on inter- and trans-disciplinarity).

3. Organizing online teaching activities in parallel with the classic activities of teaching practice (these classes being coordinated by the supervising practice teacher from DPPD) in order to supplement the class attendance activity (carried out only in 2 schools out of the 10 schools involved in the specializations considered in this study) and having deadlines posted every 2 weeks.

These online activities were mostly asynchronous (topics uploaded on Google Classroom) but some were also synchronous meetings, e.g. mainly for feedback, evaluation or inter-evaluation.

Preservice science teachers were proposed the following structure of Teaching Practice activities:

- Designing and implementing 4 online or offline teaching activities / lessons, posting lesson plans on Google Classroom and discussing them with their supervisor from WUT or their practice tutors.

- Online Activity 1: a synchronous online activity on the topic of electronic presentations, types of presentations and their adaptation for ERT (with emphasis on Mentimeter https://www.mentimeter.com/ and Google presentations applications).

- Assisting to didactic activities in the application schools (in general the students received the materials used by the teachers and explanations on how they were used in the online teaching) where they did not actually participate in the didactic process. 
- Online Activity 2: posting at least 2 assistance sheets, online formative evaluation sheets / quizzes, individual activity sheets, tests or activities designed with various applications (Wordwall https://wordwall.net/ro, Kahoot https://kahoot.com/, Quizlet https://quizlet.com/, Quizizz https:// quizizz.com/, Google Forms, etc.) on a virtual panel (Padlet https:// padlet.com/)- which would be followed by peer evaluation (at least 2 colleagues) of the posted file (fig. 2).

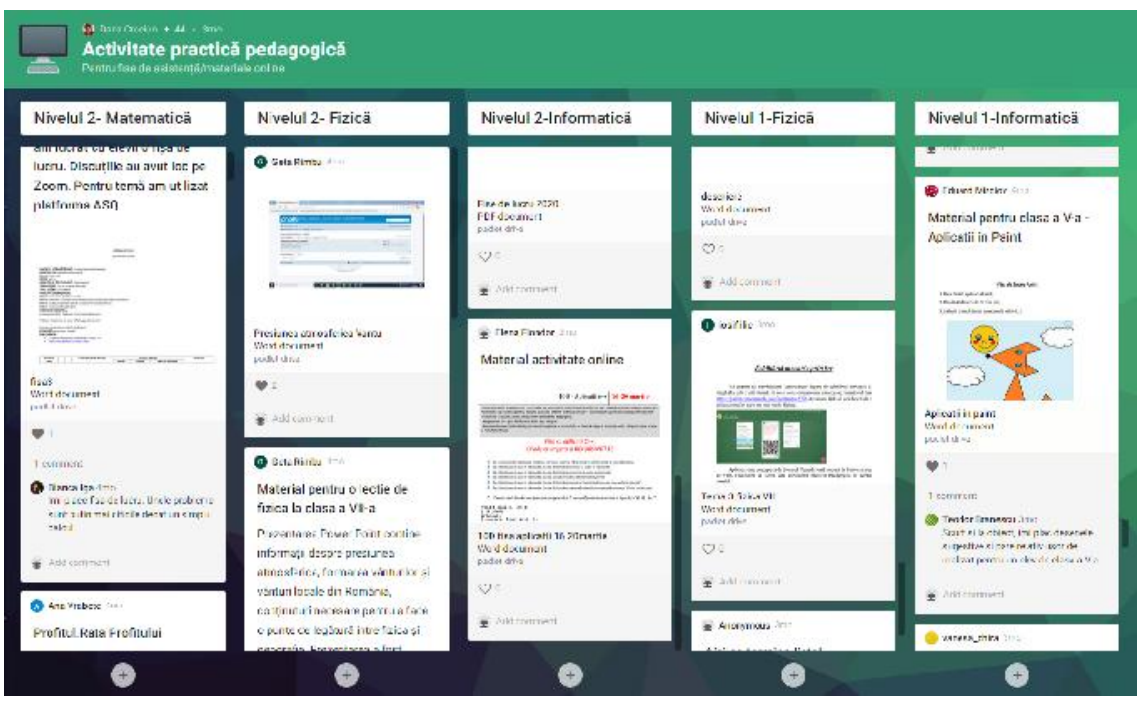

Figure no. 2. Science preservice teachers' posts on the collaborative Padlet panel

- Online Activity 3: assisting/watching to lessons simulated by the student - each student was asked to record using Flipgrid flipgrid.com two distinct lesson moments aimed at two of the lessons that would be taught or were taught (fig. 3). The moments were watched by colleagues and then evaluated and discussed with teachers in a synchronous activity on Google Meet. Thus, preservice science teachers were able on the one hand to self-correct their didactic performance by making successive recordings, and on the other hand to follow at the most appropriate time for each of them the activities performed by colleagues - learning flexibility. 

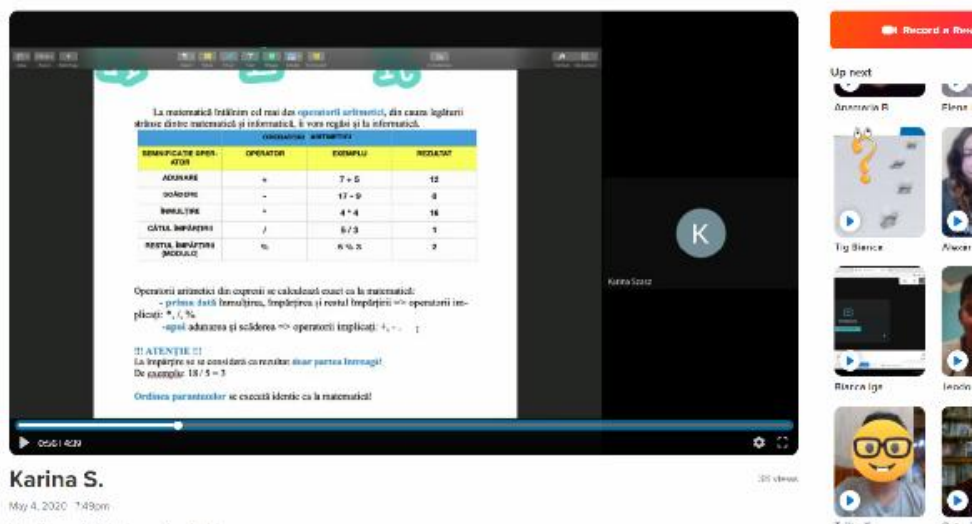

Figure no. 3. Sample teaching activity posted on Flipgrid

- Online Activity 4: optional - aimed at designing a flipped classroom activity and creating a support material (interactive video) using the Edpuzzle https://edpuzzle.com/ application.

- The evaluation of the teaching practice activity was made online by the teachers involved from both the university and pre-university level, the students presenting their activities and discussing together with all colleagues from the same specialization, in a synchronous final session on Google Meet. This online meeting focused on:

- The presentation of a practice portfolio which included the activities above.

- The description of an activity carried out online in the application school where the internship activity took place.

- Individual or group reflections on the didactic activity carried out online.

To create teaching materials, attendance sheets or lesson plans, students were provided with internationally recommended software tools and various local resources, such as

- Educred - An online platform launched by the Ministry of Education and Research which centralizes different types of free digital resources. 
- Manuale - The digital version of all school textbooks approved by the Ministry of Education and Research.

- Telescoala - A partnership between the Ministry of Education and Research and the Romanian National Television TVR(on YouTube, on the program's Facebook page, and on the websites of the TV channels) taken from the UNESCO report https://en.unesco.org/covid19/ educationresponse/nationalresponses.

- https://www.digitaliada.ro/, https://digitaledu.ro/,https://emalascoala.ro/ etc.

\section{Results and discussions: opinions of prospective teachers concerning the implementation of ERT}

\subsection{Participants}

The study targets 33 preservice science teachers at Level 1 (Physics, Computer Science specializations) and 20 preservice science teachers at Level 2 (Physics, Computer Science and Mathematics specializations).

Of the 53 preservice science teachers involved in teaching activities, 33 answered all questions off the applied questionnaire, i.e. 62.3\%. With Level 2 students also included, $19.9 \%$ of respondents said they were already working in pre-university education as substitute teachers.

\subsection{Findings}

First, we were interested in the devices and the digital resources used by preservice science teachers in the transition from face-to-face to distance learning. Thus, $80 \%$ used a desktop or laptop, and $52 \%$ a smartphone, which in the future involves rethinking the teaching materials offered to preservice teachers for mobile learning. As tools for synchronous learning, $82.5 \%$ used Google Meet, and for asynchronous learning 75\% Google Classroom, 17.5\% Moodle and 12.5\% Microsoft Teams.

Regarding software applications, $90 \%$ of preservice science teachers stated that they used the Google suite for education, followed by resource repositories such as YouTube, Flickr, etc., presentation editors, applications for online 
tests and questionnaires, open resources accessible online and various applications respectively for formative assessment. Resources such as wiki applications, collaborative sites or comic book applications were less used. Given the diversity of digital tools used in ERT and the imminent start of the new academic year, we can assume that at least some of these software applications will be used in case of face-to-face or blended learning.

Secondly, we were interested in the technological and pedagogical issues that posed a challenge for preservice science teachers in the transition from face-to-face to distance learning.

They considered that the teacher's discomfort in using technology / lack of integration of specific applications to online teaching and unclear expectations regarding the technology and applications they are required to use were the biggest technical challenge, a result that is in contradiction with the confidence of teachers at WUT, and implicitly DPPD, that distance education tools are clear and easy to understand, being easy for them to implement (Bunoiu et al., 2020).

The main learning issue (in the transition to distance learning) identified by preservice teachers was their personal preference for face-to-face learning. In general, preservice science teachers were confident in their digital skills and they consider themselves familiar with the technologies or applications needed for online interaction.

Preservice science teacher main concern in this period was the level of completion of the requirements of the proposed practical activities and the evaluation good performance in class. They were least concerned about personal needs (home and food safety) and online privacy or protection of their personal data. This may indicate, on the on hand, that students are not concerned with this last issue, but also those who are, consider that the WUT has ensured their access to education in a safe environment.

Starting from the difficulties identified by the DPPD teachers in the case of distance teaching, we were also interested in the opinion of the future teachers on the teaching competencies acquired within DPPD, particularly after completing their online learning period (table 2). 
Table no. 2. Competences formed after the Teacher training program (1 total disagree- 5 total agree)

\begin{tabular}{|r|l|c|c|}
\hline & Preservice teacher competence & Score & $\begin{array}{c}\text { Standard } \\
\text { Deviation }\end{array}$ \\
\hline 1. & $\begin{array}{l}\text { I know various e-learning strategies (synchronous / asynchronous, } \\
\text { individual / collaborative, etc.) and can apply them selectively } \\
\text { according to the advantages of each of them }\end{array}$ & 4.333 & 0.828 \\
\hline 2. & I have improved my digital skills and media skills & 4.167 & 1.028 \\
\hline 3. & $\begin{array}{l}\text { I know how to use online applications to facilitate the teaching of } \\
\text { the content of my discipline }\end{array}$ & 4.472 & 0.774 \\
\hline 4. & $\begin{array}{l}\text { I can coordinate and evaluate individual or group projects based on } \\
\text { online accessible applications }\end{array}$ & 4.083 & 1.079 \\
\hline 5. & $\begin{array}{l}\text { I can integrate a diversified palette of collaborative web 2.0 } \\
\text { applications in the teaching process }\end{array}$ & 4.056 & 1.040 \\
\hline 6. & I know various applications to integrate blended learning & 4.222 & 0.797 \\
\hline 7. & $\begin{array}{l}\text { I know how to search / select and integrate open educational } \\
\text { resources accessible online }\end{array}$ & 4.389 & 0.766 \\
\hline 8. & $\begin{array}{l}\text { I can integrate useful applications to motivate my students for } \\
\text { online learning in their specialization }\end{array}$ & 4.278 & 0.849 \\
\hline 9. & $\begin{array}{l}\text { I can create educational resources (presentations, concept maps, } \\
\text { quizzes, tests, etc.) useful in my own teaching activity }\end{array}$ & 4.500 & 0.775 \\
\hline 10. & $\begin{array}{l}\text { I became aware of the need for a pedagogical foundation for the } \\
\text { efficient use of ICT in teaching activities }\end{array}$ & 4.528 & 0.696 \\
\hline 11. & $\begin{array}{l}\text { I have developed effective communication skills (verbal, written, } \\
\text { and multimedia in a variety of styles and contexts) }\end{array}$ & 4.167 & 0.878 \\
\hline 12. & $\begin{array}{l}\text { I am confident in my ability to integrate ICT into my online / } \\
\text { blended / face-to-face teaching activities }\end{array}$ & 4.417 & 0.692 \\
\hline
\end{tabular}

All answers received to this question, as a percentage, are presented in figure 4.

\section{Science preservice teachers competences}

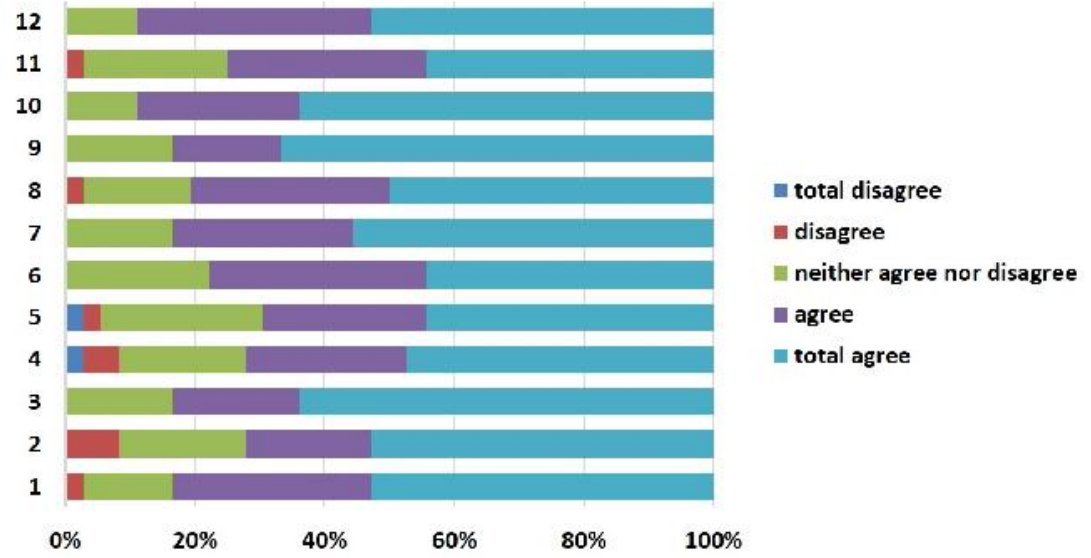

Figure no. 4. Preservice science teachers' competences formed during/after completing the initial teacher training program 
Thus, preservice science teachers consider that first of all they have become aware of the need for a pedagogical foundation for the efficient use of ICT in teaching activities, respectively that they can create educational resources (presentations, concept maps, quizzes, tests, etc.) useful in their own teaching activity. This indicates that the period spent online did not affect their opinion on the teaching activity based on technology and favoring the creation of digital educational resources.

Less developed skills are those of online communication and use of collaborative applications (in the teaching process). This result reflects the way in which the teaching activities took place, at least during the ERT period, and respectively that they have felt that the difficulty in teaching was primarily the lack of tools for feedback. The former aspect is in accordance with the opinion of DPPD teachers who considered that pedagogical aspects matter most in distance teaching (statement made by $73 \%$ of DPPD teachers). We observed that there is a close connection between the resources, methods and tools used by future teachers in the training process and the confidence in their subsequent use (Admiraal et al., 2016; Starkey, 2020).

Finally, we were interested in the science preservice teachers' opinion on the concerns (figure 5) and opportunities (figure 6) regarding the transition to distance learning - in their future teaching activity.

For this last two questions in the questionnaire, they could tick all the answers that apply. 


\title{
Science preservice teachers opinions -future teaching activity
}

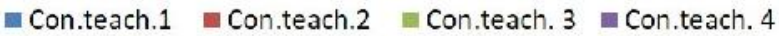 \\ Con.teach. $5 \backsim$ Con.teach. 6 Con.teach. 7 Con.teach. 8 \\ a Con.teach. 9 Con.teach. 10 Others
}

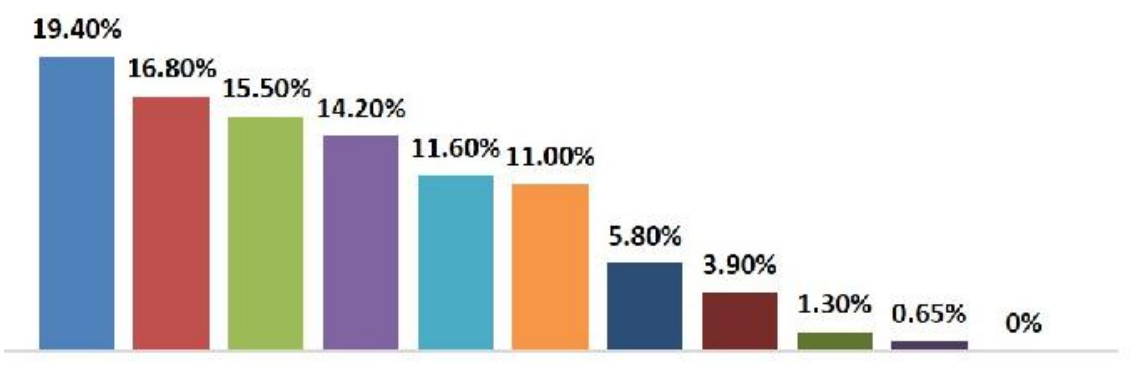

Concerns for the future teaching activity

Figure no. 5. Preservice science teachers' concerns about the future online teaching activity (as a teacher)

With the following items:

Con.teach.1. Lack of necessary technology in school or support for its use in the classroom / in teaching

Con.teach.2. Lack of a coherent strategy at the level of the educational institution regarding the management of online activities

Con.teach.3. Absence of students' autonomous learning skills (secondary / high- school / higher education level)

Con.teach.4. Increasing cybersecurity risks, exam fraud, intellectual property concerns

Con.teach.5. Lack of potential involvement in monitoring activities and student progress (primary / secondary school level)

Con.teach.6. Job security, considering the restructuring of the teaching process

Con.teach.7. My limited ability to provide students with varied opportunities to express what they have learned

Con.teach.8. My limited ability to provide students with a variety of learning resources and communication channels 
Con.teach.9. My limited ability to select the optimal tool to enhance the online learning of pupils / students folded on the type of skills developed Con.teach.10. My discomfort or limited skills regarding the integration of technology in a specific pedagogical context and folded on the contents taught Con.teach.11. Others

We observed that the lack of technology in school or the support for its use was the biggest concern of preservice science teachers. Nevertheless, they were confident in their ability to select the right technology, regardless of the type of skills they would have to develop in their students.

The major opportunities identified by future teachers, following the pedagogical practice activities carried out online in ERT, regarding their future teaching activity aim at accelerating the integration of technology in the classroom and increasing the learning autonomy of students. These opportunities were also identified by the DPPD teachers for university education and are in agreement with the opinions expressed at international level (Marinoni et al., 2020; UN Report, 2020).

All answers targeting online teaching opportunities, as a percentage, are presented in fig. 6 .

\section{Science preservice teachers opinions -future teaching activity}
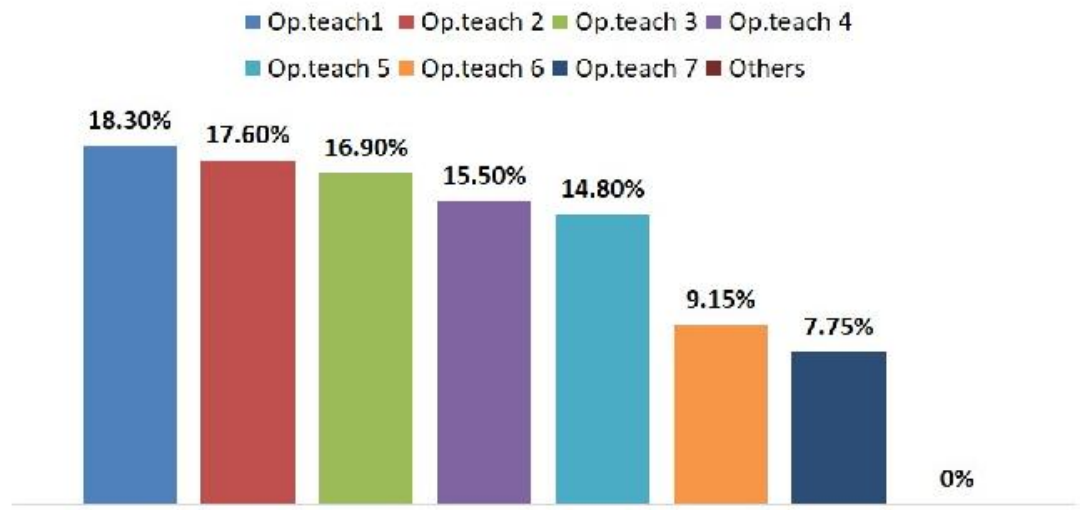

Opportunities for the future teaching activity

Figure no. 6. Opportunities about the future online teaching activity 
With the following items:

Op.teach1. There is the possibility to take accelerated steps in the integration of technology in the classroom, a situation that will remain even after the end of the crisis (for some applications / tools / pedagogical methods)

Op.teach2. Students develop an autonomy in learning, have taken control of their own learning, to explore new ideas and experiences

Op.teach3. Teachers have the chance to be creative and design challenging learning activities for their students

Op.teach4. Many companies in the field of education offer their tools / technology free of charge to support teachers and students.

Op.teach5. There are unprecedented opportunities for interdisciplinary cooperation, finding creative solutions and trying new tools.

Op.teach6. The opportunity for increased collaboration of teachers to solve the current problems generated by online teaching, the formation of online communities

Op.teach7. It is an excellent opportunity for teachers to establish closer links with their students

Op.teach8. Others

Finally, preservice science teachers considered that this period did not lead to the formation of a closer relationship between teachers and their students, respectively it was not a period of online collaboration, not even between their teachers. This result may also reflect the experience gained in online pedagogical practice, many tutor teachers maintaining minimal contact with their students, the activity being focused on sending teaching materials and evaluating homework.

\subsection{Limitations}

This study also presents limitations, given primarily by the small number of respondents, but also by the fact that the data are self-reported, i.e. obtained by applying a survey. It is also noteworthy that we cannot generalize the results obtained in this study to the level of all initial training programs for prospective science teachers in Romania, because the opinions of the participants were influenced by the particularities of the teaching process in ERT at the WUT. 
Nevertheless, we consider that our study is relevant for the initial training of the science teachers at DPPD within the WUT, as the study involved over $60 \%$ of all the preservice science teachers in training at WUT.

\section{Conclusions}

In this article we presented the strategy adopted at the West University of Timisoara (WUT) and the Teacher Training Department (DPPD) for the Emergency Remote Teaching (ERT) period during the second semester of the academic year 2019-2020, exemplifying in detail the way in which the teaching practice activity of preservice science teachers was organized.

In order to see how this period was perceived by the preservice science teachers, we applied a short questionnaire, with items build on the specific educational process in DPPD. We found that although it was a difficult period, preservice science teachers considered it a valuable experiential learning for their future profession, seeing opportunities for both teachers and their students. It is gratifying to observe that they considered themselves ready to support technology-based teaching activities, being confident in their ability to select digital resources and aware of the need for a pedagogical foundation of the online teaching approach.

We also identified the technological and learning difficulties encountered by the preservice science teachers. We noticed that although the lack of adaptation of courses and seminars for the online environment is pointed out, there were other activities and personal preferences (for learning faceto-face) that made learning more difficult.

Last but not least, this study shows the need for training in-service teachers, including university teachers, for online teaching, both in terms of integration of digital resources and tools, and especially in terms of the strategy adopted to encourage self-regulated, flexible learning with learning outcomes clearly communicated to their students. 


\section{References}

- Admiraal, W., vanVugt, F., Kranenburg, F., Koster, B., Smit, B., Weijers, S., \& Lockhors, D. (2016). Preparing pre-service teachers to integrate technology into K-12 instruction: Evaluation of a technology-infused approach. Technology, Pedagogy and Education, 26(1), 105-120.

https://doi.org/10.1080/1475939X.2016.1163283

- Doucet, A., Netolicky, D., Timmer, K., \& Tuscano, F. J. (2020). Thinking about Pedagogy in an Unfolding Pandemic, Independent Report.

https://francisjimtuscano.com/2020/04/13/independent-report-to-unesco-eithinking-about-pedagogy-in-an-unfolding-pandemic/

- Bates, A.W. (2020, March 9). Advice to those about to teach online because of the corona-virus. https://www.tonybates.ca/2020/03/09/advice-to-those-aboutto-teachonline-because-of-the-corona-virus/.

- Bates, A.W. (2019). Teaching in a Digital Age [second edition]. BCcampus https://opentextbc.ca/teachinginadigitalage/

- Bao, W. (2020). COVID-19 and online teaching in higher education: A case study of Peking University. Hum Behav \& Emerg Tech., 2, 113- 115. https://doi.org/10.1002/hbe2.191

- Bower, M., \& Torrington, J. (2020). Educase Report. https://library.educause.edu/ resources/2020/4/typology-of-free-web-based-learning-technologies

- Bran, R., \& Grosseck, G. (2020). Press RESET: Digitalizing Education in Disruptive Times. Revista Romanească pentru Educa ie Multidimensională, 12(1Sup2), 39-48. https://doi.org/10.18662/rrem/12.1sup2/245

- Bunoiu, M., Ilie, M., Cimpoca, B., Smarandache, I., \& Cherecheş, V. (2020). Carrying out the teaching process in online regime at Western University from Timişoara - the perspective of the staff teaching. https://cda.uvt.ro/wp-content/ uploads/2020/05/UVT-proces-didactic-online-Raport-mai-2020.pdf

- Hodges, Ch., Moore, S., Lockee, B., Trust, T., \& Bond, A. (2020, March 27). The Difference Between Emergency Remote Teaching and Online Learning. EDUCAUSE. https://er.educause.edu/articles/2020/3/the-differencebetween-emergency-remote-teaching-and-online-learning

- Huang, R.H., Liu, D.J., Guo, J., Yang, J.F., Zhao, J.H., Wei, X.F., Knyazeva, S., Li, M., Zhuang, R.X., Looi, C.K., \& Chang, T.W. (2020). Guidance on Flexible Learning during Campus Closures: Ensuring course quality of higher education in COVID-19 outbreak. Smart Learning Institute of Beijing Normal University.

- McAleavy, T. \& Gorgen, K. (2020). Report Overview of emerging country level response to providing educational continuity under COVID-19 Best practice in pedagogy for remote teaching, EdTech and coronavirus (COVID-19) series. https://edtechhub.org/coronavirus/resources-and-tools/ 
- Starkey, L. (2020). A review of research exploring teacher preparation for the digital age. Cambridge Journal of Education, 50(1), 37-56.

https://doi.org/10.1080/0305764X.2019.1625867

- International Association of Universities. COVID-19: Higher Education challenges and responses.

https://www.iau-aiu.net/COVID-19-Higher-Education-challenges-and-responses

- Marinoni, G., van't Land, H., \& Jensen, T. (2020). IAU Global Survey Report The impact of COVID-19 on Higher Education around the world.

https://www.iau-aiu.net/IMG/pdf/iau_covid19_and_he_survey_report_final_ may_2020.pdf

- COL (2020). Guidelines on Distance Education during COVID-19. COL. http://oasis.col.org/bitstream/handle/11599/3576/2020_COL_Guidelines_ Distance_Ed_COVID19.pdf?sequence=4\&isAllowed=y

- Educause Covid 19 Data Bytes. https://er.educause.edu/columns/data-bytes

- UNESCO Covid19 Resources. https://en.unesco.org/covid19/educationresponse/solutions

- UNESCO Report (2020, April 3). COVID-19 Educational Disruption and Response. https://www.unicef.org/coronavirus/covid-19

- United Nations (2020, August 4). Policy Brief: Education during COVID 19 and beyond. https://www.un.org/development/desa/dspd/wp-content/ uploads/ sites/22/2020/08/sg_policy_brief_covid-19_and_education_august_2020.pdf

- The World Bank Resources. https://www.worldbank.org/en/topic/edutech/brief/ edtech-covid-19

The online version of this article can be found at: http://revped.ise.ro/category/2020-en/

\section{$(\mathrm{Cc}))$ BY-NC-BA}

This work is licensed under the Creative Commons Attribution-NonCommercial-ShareAlike 4.0 International License.

To view a copy of this license, visit http://creativecommons.org/licenses/by-nc-sa/4.0/ or send a letter to Creative Commons, PO Box 1866, Mountain View, CA 94042, USA.
Versiunea online a acestui articol poate fi găsită la: http://revped.ise.ro/category/2020-ro/

\section{$(c))$ Br-ne-sa}

Această lucrare este licen iată sub Creative Commons Attribution-NonCommercial-ShareAlike 4.0 International License.

Pentru a vedea o copie a acestei licen e, vizita $i$ http://creativecommons.org/licenses/by-nc-sa/4.0/ sau trimite i o scrisoare către Creative Commons, PO Box 1866, Mountain View, CA 94042, SUA. 